\title{
Antimicrobial Activity and Fatty Acids from Ipomea ochraceae
}

\section{Idowu OT* and Ojo OA}

Department of Industrial Chemistry, Afe Babalola University, Afe Babalola Way, Ado Ekiti, Nigeria

\begin{abstract}
Ipomea ochraceae is from the family Convolvuliacea. It is mainly referred to as weed. The whole plant was air-dried, crushed into powdery form and then extracted using ethanol. The purpose of this study is to determine its antimicrobial activity and fatty acids from the constituents derived from GC-MS analysis.
\end{abstract}

Keywords: Ipomea ochraceae; Fatty acids; Antimicrobial activity

\section{Introduction}

The family Convolvulaceae includes about 57 genera and 1625 species [1]. It is also called morning glories have many special meanings to different people. They decorate our world with beautiful flowering vines and provide us with some nutritious and delicious vegetables. Morning glories are splendid for enhancing fences or for covering up eyesores. They rapidly cover fences, arches, pergolas, and trellises or can be made into their own garden feature with stakes and twine [2].

Fatty acids, both saturated and unsaturated play a key role in metabolism, as a metabolic fuel, as a necessary component of all membranes and as a gene regulator. In addition, fatty acids have a number of industrial uses [3]. Obtaining fatty acids from plant sources is more beneficial for one's health. A well-planned plant based diet fatty acids rich food promotes heart health, ensuring the proper growth and development of your child and relieving pain. In this present study, focus shall be mainly on the antimicrobial activity and fatty acids from Ipomea ochracea [3].

\section{Materials and Methods}

\section{Plant material and general experimental methods}

Fresh leaves of Ipomea ochracea were collected in the month of November, 2016 from Afe Babalola University, Ado-Ekiti (ABUAD) Ekiti state, Nigeria. The plant was authenticated by the herbarium staff of the Botanical department at the Ekiti State University.

\section{Sample preparation}

$950 \mathrm{~g}$ of the leaves were air dried at room temperature for about seven days. Thereafter, the dried leaves were pulverized and extracted using $95 \%$ ethanol at room temperature. The extracts were concentrated to dryness and the residue were obtained as a greenish black solid, after which the residues were transferred into a pre-weighed sample containers and were stored and later used for phytochemical screening and antioxidants activity.

\section{Antimicrobial screening}

The agar diffusion (cup plate) method was used for this examination. Molten and cooled agar $60 \mathrm{ml}\left(45^{\circ} \mathrm{C}\right)$ were separately inoculated with the nutrient broth culture of the test organisms $(0.6 \mathrm{ml})$ and mixed thoroughly. The inoculated medium was then carefully poured into sterile Petri dishes (24 cm Petri dish) and allowed to set. Thereafter, cups ( $9 \mathrm{~mm}$ diameter) were aseptically bored into the solid nutrient agar using a sterile cork borer. The test solutions $100 \mu \mathrm{L}$ each were then introduced into each of the cups ensuring that no spillage occurred.

Also, the same volume of the standard antimicrobial agent and the solvent were introduced into some of the cups to act as positive and negative controls respectively. The plates were left at room temperature for 2 hours to allow for diffusion into the medium and thereafter incubated face upwards at $37^{\circ} \mathrm{C}$ for 24 hours. Sample was tested in duplicate and the diameters of zone of inhibition were measured to the nearest millimeter using a transparent ruler.

\section{GC-MS}

The GC was carried out using Hewlett- Packard 6890 GC series equipped with FID and HP-5 capillary column (cross linked 5\% diPh, 95\% dimethylpolysiloxane, $30 \mathrm{~m} \times 0.32 \mathrm{~mm}$ i.d.; $0.25 \mu \mathrm{m}$ film thickness). The column temperature was programmed at $50-210$ at a rate of $3^{\circ} \mathrm{C} /$ min. The injector and detector temperatures were $220^{\circ} \mathrm{C}$ and $270^{\circ} \mathrm{C}$, respectively. Samples $(1 \mu \mathrm{L}$ of the oil solutions in chloroform, $2 \mathrm{mg} /$ $\mathrm{mL}$ ) were injected by the split less technique into nitrogen carrier gas $(0.8 \mathrm{~mL} / \mathrm{min})$.

\section{Results}

The results have been explained with the aid of Plates 1 and 2 (Tables 1 and 2).

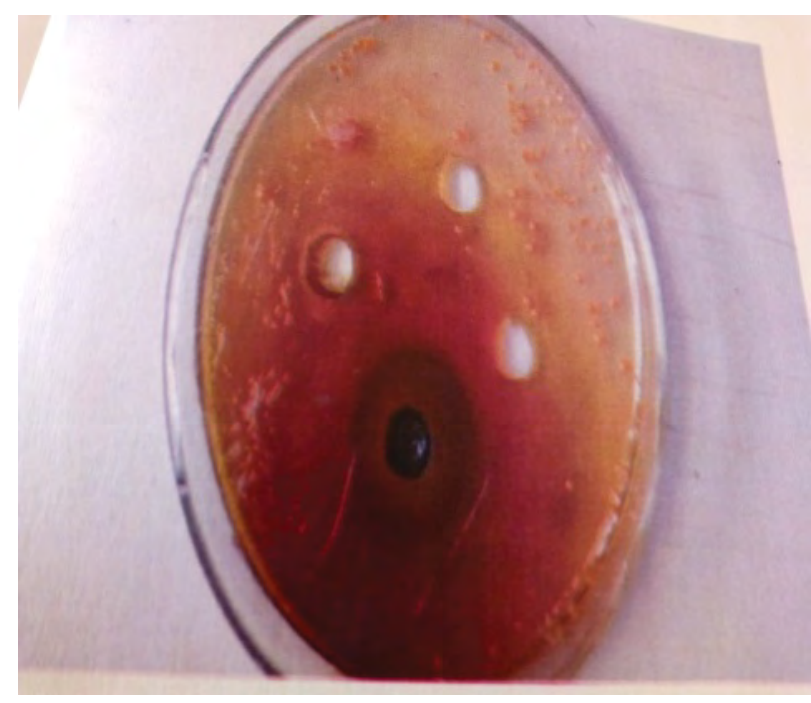

Plate 1: Antimicrobial activity of Ipomea ochracea (Ethanol extract).

*Corresponding author: Idowu OT, Department of Industrial Chemistry, Afe Babalola University, Afe Babalola Way, Ado Ekiti, Nigeria, Tel: +2348037400826; E-mail: jumokeye@gmail.com

Received October 03, 2017; Accepted October 16, 2017; Published October 21 2017

Citation: Idowu OT, Ojo OA (2017) Antimicrobial Activity and Fatty Acids from Ipomea ochraceae. Med Chem 7: 299-301. doi: 10.4172/2161-0444.1000471

Copyright: @ 2017 Idowu OT, et al. This is an open-access article distributed under the terms of the Creative Commons Attribution License, which permits unrestricted use, distribution, and reproduction in any medium, provided the original author and source are credited. 
Citation: Idowu OT, Ojo OA (2017) Antimicrobial Activity and Fatty Acids from Ipomea ochraceae. Med Chem 7: 299-301. doi: 10.4172/21610444.1000471

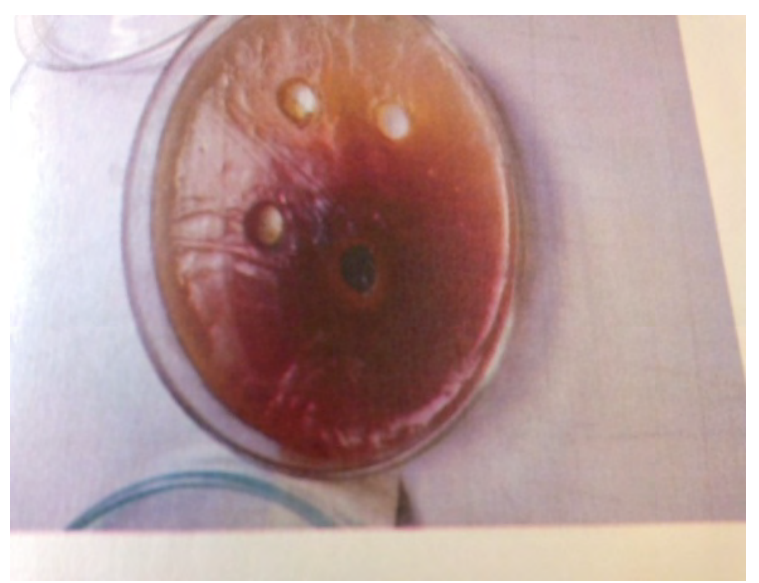

Plate 2: Antimicrobial activity of Ipomea ochracea (Hexane extract).

\begin{tabular}{|c|c|c|c|c|c|c|}
\hline Samples & $\mathbf{E}_{1}$ & $\mathbf{E}_{\mathbf{2}}$ & $\mathbf{C n E}$ & $\mathbf{H}_{1}$ & $\mathbf{H}_{2}$ & $\mathbf{C n H}$ \\
\hline $\begin{array}{c}\text { B. cereus } \\
\text { NCIB 950 }\end{array}$ & $16.0(\mathrm{~S})$ & $11.0(\mathrm{~S})$ & $0.0(\mathrm{R})$ & $10.0(\mathrm{~S})$ & $10.0(\mathrm{SR})$ & $0.0(\mathrm{R})$ \\
\hline $\begin{array}{c}\text { E. coli } \\
\text { NCIB 86 }\end{array}$ & $0.0(\mathrm{R})$ & $0.0(\mathrm{R})$ & $0.0(\mathrm{SR})$ & $0.0(\mathrm{R})$ & $0.0(\mathrm{R})$ & $0.0(\mathrm{R})$ \\
\hline $\begin{array}{c}\text { S. aureus } \\
\text { NCIB 8588 }\end{array}$ & $18.0(\mathrm{~S})$ & $20.0(\mathrm{~S})$ & $0.0(\mathrm{R})$ & $13.0(\mathrm{~S})$ & $16.0(\mathrm{SR})$ & $0.0(\mathrm{R})$ \\
\hline $\begin{array}{c}\text { Serratia mercescens } \\
\text { NCIB 1377 }\end{array}$ & $0.0(\mathrm{R})$ & $0.0(\mathrm{R})$ & $0.0(\mathrm{R})$ & $18.0(\mathrm{SR})$ & $24.0(\mathrm{SR})$ & $0.0(\mathrm{R})$ \\
\hline Aspergillus flavus & $0.0(\mathrm{R})$ & $0.0(\mathrm{R})$ & $0.0(\mathrm{R})$ & $0.0(\mathrm{R})$ & $0.0(\mathrm{R})$ & $0.0(\mathrm{R})$ \\
\hline Fusarium species & $0.0(\mathrm{R})$ & $0.0(\mathrm{R})$ & $0.0(\mathrm{R})$ & $0.0(\mathrm{R})$ & $0.0(\mathrm{R})$ & $0.0(\mathrm{R})$ \\
\hline Penicillium halicum & $0.0(\mathrm{R})$ & $0.0(\mathrm{R})$ & $0.0(\mathrm{R})$ & $0.0(\mathrm{R})$ & $0.0(\mathrm{R})$ & $0.0(\mathrm{R})$ \\
\hline Trinchodern vinde & $0.0(\mathrm{R})$ & $0.0(\mathrm{R})$ & $0.0(\mathrm{R})$ & $0.0(\mathrm{R})$ & $0.0(\mathrm{R})$ & $0.0(\mathrm{R})$ \\
\hline Trichrophytn rubrum & $0.0(\mathrm{R})$ & $0.0(\mathrm{R})$ & $0.0(\mathrm{R})$ & $0.0(\mathrm{R})$ & $0.0(\mathrm{R})$ & $0.0(\mathrm{R})$ \\
\hline Candida alblicans & $22.5(\mathrm{R})$ & $25.0(\mathrm{R})$ & $0.0(\mathrm{R})$ & $11.0(\mathrm{R})$ & $14.0(\mathrm{R})$ & $0.0(\mathrm{R})$ \\
\hline Table 1:Zones
\end{tabular}

Table 1: Zones of inhibition (diameter mm; less cup size) of Ipomea ochraceae crude ethanol and hexane extracts at $100 \mathrm{mg} / \mathrm{ml}$ and $25 \mathrm{mg} / \mathrm{ml}$.

\begin{tabular}{|c|c|c|c|}
\hline Peak & Retention time & Area & Name \\
\hline 1 & 9.017 & 0.24 & 2,4-Pentadienoic acid, 1-cyclopenten-3-on-1 \\
\hline 2 & 9.789 & 0.55 & n-Decanoic acid \\
\hline 3 & 10.11 & 0.31 & Decanoic acid, ethyl ester \\
\hline 4 & 10.22 & 0.15 & 1-Pentanol, 4-methyl-2-propyl \\
\hline 5 & 10.66 & 0.39 & Bicyclo[7.2.0]undec-4-ene,4,11, trimeth \\
\hline 6 & 11.42 & 0.15 & 1,6-cyclodecadiene, 1-methyl \\
\hline 7 & 11.75 & 0.28 & Tridecanoic acid, methyl ester \\
\hline 8 & 12.36 & 8.92 & Dodecanoic acid \\
\hline 9 & 12.64 & 5.17 & Dodecanoic acid, ethyl ester \\
\hline 10 & 15.32 & 6.06 & Tetradecanoic acid \\
\hline 11 & 15.69 & 3.31 & Tetradecanoic acid, ethyl ester \\
\hline 12 & 15.81 & 0.23 & Sulfurous acid, decyl 2-propyl ester \\
\hline 13 & 17.55 & 1.26 & Cis-9-Hexadecenoic Tetradecanoicacid, ethylester acid \\
\hline 14 & 17.82 & 24.07 & n-Hexadecanoic acid \\
\hline 15 & 18.70 & 0.17 & 9,9 Dimethoxybicyclo[3,3,1] nona-2,4-dione \\
\hline 16 & 19.04 & 0.59 & 9,12-Octadecadienoic acid \\
\hline 17 & 19.25 & 0.45 & Phytol \\
\hline 18 & 19.51 & 27.04 & 9-Octadecenoic acid,(E) \\
\hline 19 & 19.71 & 9.72 & Octadecanoic acid \\
\hline 20 & 20.70 & 0.84 & Erythro-9,10-Dibromopentacosane \\
\hline 21 & 21.286 & 1.91 & Eicosanoic acid \\
\hline 22 & 21.70 & 0.12 & Erythro-9,10-dibromopentacosane \\
\hline 23 & 22.317 & 1.65 & Hexadecanoic acid, 1(hydroxymethyl)-1,2-ethanediyl \\
\hline 24 & 22.591 & 4.20 & Diisooctylphthalate \\
\hline 25 & 22.765 & 2.25 & Eicosanoic acid, 2-[(1-oxohexadecyl)oxy]-1 \\
\hline
\end{tabular}

Table 2: Fatty acids from Ipomea ochracea. 
Citation: Idowu OT, Ojo OA (2017) Antimicrobial Activity and Fatty Acids from Ipomea ochraceae. Med Chem 7: 299-301. doi: 10.4172/21610444.1000471

\section{Discussion}

Ipomea ochracea ethanol extract was moderately active against $B$. cereus at the zone of inhibition $16 \mathrm{~mm}$ but its hexane extract was low at $10 \mathrm{~mm}$. Its ethanol extract was strongly active against $S$. aureus at the zone of inhibition $18 \mathrm{~mm}$ but its hexane extract was low at $13 \mathrm{~mm}$. Ipomea ochracea was not active against all other fungi mentioned from Table 1 except Candida alblicans. Ipomea ochracea ethanol extract was strongly active against Candida alblicans at the zone of inhibition 22.5 $\mathrm{mm}$ but showing low activity at $11 \mathrm{~mm}$. This plant can be used to treat various infections caused by $B$. cereus and $S$. aureus. The potency of the extract was strong in the polar portion than the non-polar portion.

Twenty-five compounds are present in the Ipomea ochracea which are majorly the fatty acids. Application of phytol can be used as one of the drugs that can be used to treat fluke's infestation.

\section{Conclusion}

The crude extract of Ipomea ochracea showed strong antimicrobial activity for the first time. The constituents of the plants revealed some fatty acids like phytol, eicosanoic acids and so on for the first time. Further investigation could be carried out to isolate the active fatty acids that could be used in the pharmaceutical industry.

\section{References}

1. Shimpak VB (2012) Ipomea ochracea (Convolvulacea) - A new record from India. Rheedea 22: 99-102.

2. Marbberley DJ (2008) The Plant Book. A portable dictionary of plants, their classification and uses. 3rd edn. Cambridge University Press, Cambridge, UK.

3. Rustan AC, Drevon AC (2005) Fatty acids: Structures and Properties. Citable Reviews in the Life Sciences. 